\title{
Adaptation of BCCT Learning Model in Developing Religious Aspects of Children
}

\author{
Abd Hamid Wahid ${ }^{\llbracket}$, Muhammad Fajri², Hasan Baharun³ ${ }^{3}$ Riana Imroatul Fitriyah ${ }^{4}$, \\ Arifatur Risqiyah ${ }^{4}$ \\ Pendidikan Agama Islam, Univesitas Nurul Jadid, Paiton Probolinggo, Indonesia(1) \\ Pendidikan Agama Islam, Universitas Islam Negeri Sultan Aji Muhammad Idris, Samarinda, \\ Indonesia( ${ }^{(2)}$; Manajemen Pendidikan Islam, Univesitas Nurul Jadid, Paiton Probolinggo, \\ Indonesia(3); Pendidikan Islam Anak Usia Dini, Univesitas Nurul Jadid, Paiton Probolinggo, \\ Indonesia ${ }^{(4)}$ \\ DOI: $\underline{10.31004 / o b s e s i . v 6 i 4.2073}$
}

\begin{abstract}
This study aims to find out and analyze the adaptation of BCCT learning models in developing religious aspects of children. With qualitative methods. The informants in the study were principals, class A teachers, and class B teachers taken with a purposive sampling approach. Preliminary observations in the field show that the implementation of early childhood learning still does not entirely refer to the stages of development and growth of children, especially in the religious aspects of children. The results of this study in implementing the BCCT learning model are the first environmental footing by preparing places and conditions before learning. Second, the footing of the experience before playing is also referred to as the opening activity before entering the core learning activities. Third, the footing when playing is the child's activity in playing a role according to the center. Fourth, footing after play is an activity carried out by teachers and children when they finish playing.
\end{abstract}

Keywords : bcct learning model; children's religious aspects; early childhood

\begin{abstract}
Abstrak
Penelitian ini bertujuan untuk mengetahui dan menganalisis tentang adaptasi model pembelajaran BCCT dalam mengembangkan aspek keagamaan anak. Dengan metode kualitatif. Informan dalam penelitian ini adalah kepala sekolah, guru kelas A, dan guru kelas B yang diambil dengan pendekatan purposive sampling. Observasi awal di lapangan menunjukkan bahwa pelaksanaan pembelajaran anak usia dini masih belum sepenuhnya mengacu pada tahapan perkembangan dan pertumbuhan anak, khususnya pada aspek keagamaan anak. Hasil penelitian menunjukkan bahwa penerapan model pembelajaran BCCT dilakukan melalui; Pertama, berpijak pada lingkungan dengan mempersiapkan tempat dan kondisi sebelum pembelajaran. Kedua, pijakan pengalaman sebelum bermain, disebut juga sebagai kegiatan pembukaan sebelum memasuki kegiatan inti pembelajaran. Ketiga, pijakan saat bermain adalah aktivitas anak dalam memainkan peran sesuai dengan pusatnya. Keempat, pijakan setelah bermain adalah kegiatan yang dilakukan oleh guru dan anak setelah selesai bermain.
\end{abstract}

Kata Kunci: model pembelajaran bcct; religius; anak usia dini

Copyright (c) 2022 Abd Hamid Wahid, et al.

$\triangle$ Corresponding author :

Email Address : hamidw@gmail.com (Paiton, Probolinggo, Indonesia)

Received 14 November 2021, Accepted 26 December 2021, Published 27 February 2022 


\section{INTRODUCTION}

Early childhood education includes the entire process of psychosocial stimulus and is not limited to the learning process in educational institutions (Adi et al., 2020). Early childhood education can occur anytime and anywhere, such as ongoing human interactions within the family, peers, and community relationships (Handayani, 2021). A good learning process for early childhood should adjust to children's needs and development (Maulidia \& Hanifah, 2020). Learning that can be developed in the excitement of early childhood education learning is the central and circular method adopted from the BCCT learning model (Beyond Centre and Circle Time) (Preuss et al., 2012). BCCT is a student-centered learning model, where learning activities are centered on the center of the play and in circle activities (Yu et al., 2016). Centerbased learning is a center of children's play activities that are expected to develop all potential and development by the stages of age through integrated stimulation (Heil et al., 2012; Nuraeni \& Irawan, 2021).

Preliminary observations in the field show that the implementation of early childhood learning still does not entirely refer to the stages of development and growth of children (Nurmiyanti \& Candra, 2019; Alfina \& Anwar, 2020), especially in the religious aspects of children, especially in Raudlatul Athfal Nurul Istiqomah Kraksaan Probolinggo as the object of this study. In general, the implementation of learning is focused on improving academic ability, both in terms of memorization, reading, writing, and numeracy; the process often ignores children's stages of development and growth. The implementation of learning activities still forgets the element of play that becomes one of the principles of early childhood education (Rozi et al., 2022).

These activities are replaced in the learning process-oriented to the academic aspect, meaning that children's activities at the institution focus more on how children learn to read, write and count by following the methods directed by the teacher (Almuhajir, 2021). Children are not given the freedom to choose activities that are by the child's interests and abilities (Susilowati \& Farida, 2019). Play becomes rare, foreign to children, sometimes even a reward for the child's behavior and competence by his teacher's expectations. This is the basis of the researcher's interest in the learning design carried out by Raudlatul Athfal Nurul Istiqomah Kraksaan Probolinggo after analyzing aspects of learning that have been done both analyses conducted by internal schools and external schools. The learning paradigm at the institution is then reconstructed with the principle of continuous improvement through implementing BCCT in its learning activities.

Entering the current era, learners can choose their way and style of learning. Because the desire or emotional mood to learn someone can appear anytime and anywhere, so when it happens then, learners need to be accommodated to be able to know immediately, including the provision of learning resources, teaching media, and learning environments (Wibawa \& Agustina, 2019). Education is an unavoidable area of development (Rasyad et al., 2020). The result of technology can create several problems; the first aspects of child development vary, even some with vandalism (Subaidi, 2020). Second, there are public demands related to the output of learners (Marini et al., 2018). People want children to have a religious character from an early age (Iltiqoiyah, 2020). People are aware that with religious symbols that are awakened from an early age, there will be mental resilience when growing up so that between inputs will produce outputs that are by expectations (Alberts, 2019).

This research is based on preliminary research submitted by Ahsanulkhaq (2019), which suggests that the formation of religious aspects must be formed through habituation methods. Hayati et al. (2020) said that school culture-based religious character education is implemented by integrating religious values in school activities. Astuti et al. (2020) noted that strategies in cultivating the spiritual aspects of children could be done through transparency, habituation, integration in teaching. 
To realize a religious character, especially in early childhood, the teacher at Raudlatul Athfal Nurul Istiqomah Kraksaan Probolinggo uses the BCCT learning model. BCCT learning model as a strategy to achieve these goals. BCCT learning model that uses centers, corners, areas aims to bring children to the experience of exploring and interacting with others and the surrounding environment. In its implementation is adjusted to the stages of child development. This approach demonstrates the importance of role-playing, sensorimotor play, and story play down to literacy skills, designed to be fun and enlightening (Lestari, 2019).

This research seeks to combine the learning model used by teachers, namely the BCCT learning model, and the concept of developing religious aspects that are part of the discipline of psychology. This is the uniqueness of two different images and used to create children who have character resilience.

\section{METHODOLOGY}

This research was conducted at Raudlatul Athfal Nurul Istiqomah Kraksaan Probolinggo using qualitative methods of case study types, which were carried out in a planned and systematic manner for one month. Researchers chose the Raudlatul Athfal institution because, based on the results of initial observations of the study, the institution prioritizes the teaching of religious and moral values to arouse the motivation and interest of learning children.

The informants in the study were principals, class A teachers, and class B teachers taken with a purposive sampling approach. To get an idea of the adaptation of the BCCT learning model in developing the religious aspects of children at the institution, researchers used in-depth interviews about learning activities through the BCCT learning model. Then, the researcher also conducts observations and documentation. The data analysis is carried out circularly, starting from the overall display data from the interviews, comments, and documentation obtained while in the field. Then the researcher conducts data reduction, which is sorting and selecting data that has been collected by the theme that has been determined so that the focus of the research will systematically arrange data. The findings of the interim study then ended with the withdrawal of research conclusions, as a study found. The research design is presented with Figure 1.

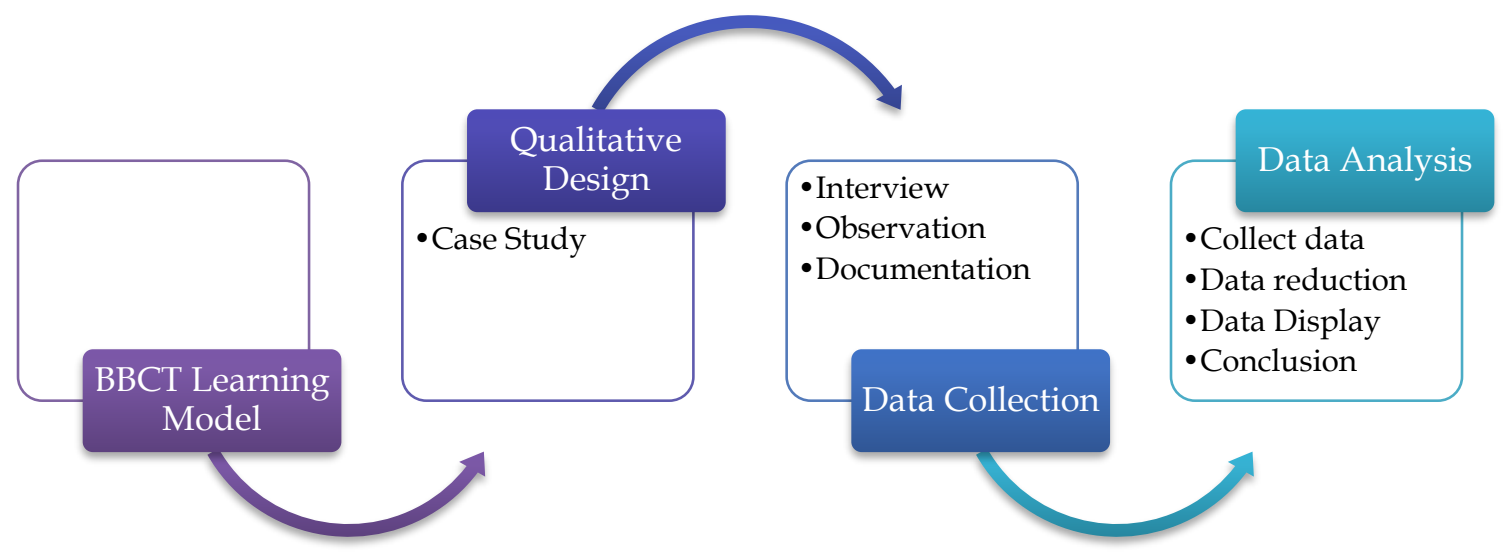

Figure 1. Research Design

\section{RESULTS AND DISCUSSIONS}

The learning process carried out has value in developing religious aspects that can be instilled and applied to early childhood, one of which is through the BCCT learning model. adaptation of bcct learning model in developing religious presented in figure 2 . 


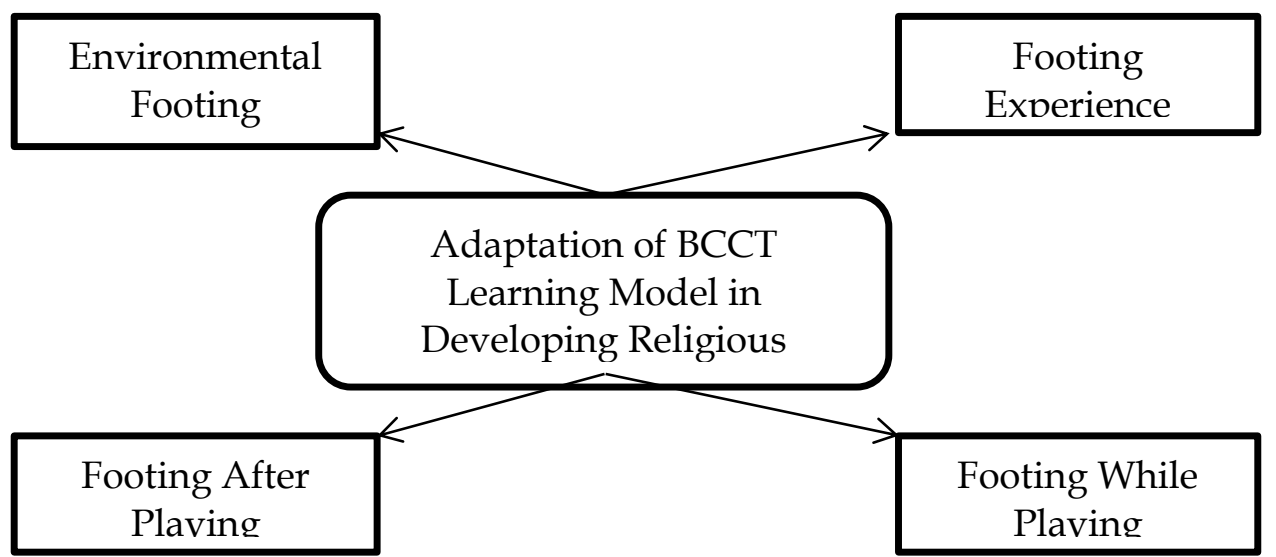

Figure 2: Adaptation of BCCT Learning Model in Developing Religious

\section{Environmental Footing}

In simple terms, the footing of the environment is the activity of teachers preparing conditions, places, equipment, administration, and others before the game is done at the center. The playing environment is designed by stretching carpets or chairs for play activities. This activity can be done outside or indoors. Theoretically, a quality playing environment supports three types of play: sensorimotor or functional play, role (macro/micro), and leading development (liquid nature of natural and structured materials).

Based on the results of observations and interviews in the first step of the BCCT approach, some things done by teachers are teachers preparing game venues and tools according to the theme, choosing the type of game, story, song, and motion, and planning learning time. The teacher's administrative preparation is to prepare observation notes and records of child development (language, social-emotional, cognitive, and moral-spiritual).

According to Sutriyani, as a class A teacher at Raudlatul Athfal Nurul Istiqomah Kraksaan Probolinggo, technological advances require education to adapt and use media in the learning process. In line with Ainul as a B class teacher in Raudlatul Athfal Nurul Istiqomah Kraksaan Probolinggo, the teacher's environmental footing conditioned the place and students at the center of the teacher's environmental base so that it can be by the theme of learning by utilizing technology.

Implementation of learning with the utilization of technological advances can facilitate learning in the center of students. When the footing of the playing environment, teachers organize central classes by preparing tables as many as 4 to 7 with circular positions and tools, materials, and learning media. In the current learning, teachers try to introduce technological media in the learning process using the tape recorder, $t v$, and LCD projectors.

The development of the world of education is changing the way of thinking about the learning process. Education emphasizes character, morals, and thorough education. This is because the knowledge that is owned is assisted by technology in implementing the learning process (Syafii et al., 2021).

\section{Footing Experience Before Playing}

Footing activities before play can also be referred to as opening activities. This activity aims to prepare the initial condition of both mental and physical children before entering the core learning activities. Opening activities are carried out by forming a small circle between educators and children. The number of one study group is at most 15 children. The activities include greetings from teachers, praying together led by one of the learners. His prayers welcomed reading two sentences of the shahada, blessing to learn, asking for intelligence, reading al-Fatihah letter, pledge, and asmaul husna, all of which were done together. Activities during the opening will train the child in all aspects, especially religious ones. 
According to Sulasmi, as the principal in Raudlatul Athfal Nurul Istiqomah Kraksaan Probolinggo, the teacher opening activities also conveyed the theme of learning, conducted perceptions, and conveyed learning goals, and provided initial motivation in the opening moves at Raudlatul Athfal Nurul Istiqomah Kraksaan Probolinggo as well. In line with the opinion of Sutriyani as a class, A teacher in Raudlatul Athfal Nurul Istiqomah Kraksaan Probolinggo said that the procedure of footing activities before playing had been carried out by teachers in Raudlatul Athfal Nurul Istiqomah Kraksaan Probolinggo. In great detail, it can be described as follows :

First, the child lines up neatly to enter the center, greets the teacher, and greeting the child teacher in an orderly manner enters the center. In this activity, children are taught to be disciplined, orderly, queuing, polite, and respectful of teachers. In this realm, the teacher has developed the religious aspect of children.

Second, while the child has been at the center, the teacher invites the child to sit in a circle on the carpet. Then the teacher began to open the learning by saying greetings, praying together, led by one of the learners. His prayers included reading two sentences of the shahada, prayer to learn, a prayer asking for intelligence, reading al-Fatihah letter, pledge, and asmaul husna, all of which were done together. The teacher also asks about the child, asks the child who did not enter the school (licensed), sings, and claps. Prayer activities and asking about children's news are exercises to develop the religious aspects of children. Activities that open with singing and clapping are fun for children because it is their psychological characteristic. A pleasant initial psychological condition will pre-state the child's learning readiness at the next stage.

Third, the activities of Dhuha prayer and continued with dhikr along with reading; istighfar, tasbih, tahmid, takbir, and tahlil. As for the equipment used, such as classrooms, prayer mats, priests, and makmum. Not forgetting in this activity, the teacher instills the child's morals, such as queuing accustomed to saying thank you for help and forgiveness.

Fourth, Mentoring Tahfidz and Qira'ati. Mentoring program is the memorization of short letters and Hadiths, where adapted to the class's ability. Hadith here alternates according to the class's ability and according to the child's age. Hadiths that must be memorized are Hadith about not to hate, Hadith about Allah's pleasure with the ridho of parents, and others. After memorizing some prescribed hadiths, the next is prayer. Some of the blessings that are read are adjusted to the ability of the class and according to the child's age, including prayers raining, prayers when hearing lightning, and others. Moral activities include being happy to kiss hands to anyone and making hand-kissing gestures to others. Aqidah activities include believing the beautiful names of Allah, including Al-Mughniy, Ar-Razzaqu, and so on, which are carried out simultaneously by children.

For tahfidz activities, each child is different according to their memorization ability, so each child has another tahfidz teacher for one class. They do their moving or change types to find their tahfidz teacher. The method used in tahfidz learning is an individual classic, where the child advances one, two, or three people to the teacher, then the teacher listens and confirms if something goes wrong. Some of the equipment needed, including guide bookstahfidz and mentoring for teachers between teachers and children. The activity begins with reading the qur'an, then learning qira'ati individually or facing the teacher, or called the sorogan system. Sorogan system is a learning system by way of children taking turns forward to educators to preach. The children alternately advanced one by one in front of the qira'ati teacher. This qira'ati teacher also included the class teacher for the tools used, such as Standard Operating Procedure (SOP) qira'ati, qira'ati books, props, achievement books, and value recaps.

Fifth, the next activity is the teacher conveying the theme of learning. This activity aims to let children know what they will learn and experience on one day of learning activities. Learning themes taken from learning devices according to the age of the child include annual programs (PROTA), semester programs (PROMES), week learning implementation plans 
(RPPM), and daily learning implementation plans (RPPH) made by teachers to achieve learning goals. One of the themes is the theme of saving.

Sixth, the teacher tells about the theme (saving) after conveying the theme. At this time, we can teach many things to children from an early age, especially in the sophistication of digital tools that continue to grow, one of which is the bank's saving system. The teacher used a medium image of the bank's front, and several corners appeared within the bank. Teachers tell the money that must be saved, saving is good behavior, saving can be done in the bank, and how to keep in the bank. The teacher used a medium image of the bank's front, and several corners appeared within the bank. Teachers tell the money that must be saved, saving is good behavior, saving can be done in the bank, and how to keep in the bank. In this activity, the teacher relates the story's content to the context of the child's daily life, including strengthening positive/negative attitudes and behaviors that must be done/avoided by children. This activity also teaches you to introduce children to new terms/vocabulary such as banks, savings books, tellers, customer services, and others. In this activity, the teacher also interspersed him with singing and clapping.

Seventh, the next step is to convey learning and game activities that will be carried out, which is the role of microbanks. In this activity, the teacher explains the game, the game tools to be used, and how to use toys. Eighth, the teacher explains the rules of the game and the length of time in play. Ninth, the teacher appoints the child as a customer, teller, customer service, security, and queue card divider. The last is a transition activity where the child is asked to be ready to play. There are about 15 minutes in this transition activity where the teacher invites the child to prepare themselves, go to the toilet, etc.

\section{Footing While Playing}

Footing activities while playing is the core activity of learning. In this activity, the child plays a role by the center he enters. They share a role in the game and take turns during the game. If one game is only for 5-10 people, then the rest of the child plays on another theme at the exact center. After completing one game, the child is rotated to play a new role. The teacher's position is only as of the facilitator who directs and organizes the game on this footing. The time required for this activity is at least 60 minutes. There are many benefits of this activity, including providing new experiences, developing communication skills, improving vocabulary mastery, developing imagination, enriching creative power, and fostering social skills.

In this playing activity, according to Ainul as a B-class teacher at Raudlatul Athfal Nurul Istiqomah Kraksaan Probolinggo said that, at the center of the micro role, some of the things done by Raudlatul Athfal Nurul include. First, teachers organize, direct and guide children towards playing the part they do. This activity is intended to supervise children, helping them if children encounter difficulties in their play activities.

Second, another thing that teachers do is provide positive reinforcement. In this BCCT approach, children construct their own experiences and knowledge, but teachers must support what children do. This activity aims to be passive such as queuing behavior while in the bank, being friendly, orderly, and so forth.

Third, while the child plays his role, the teacher invites the child to dialogue. Conducting dialogue is an activity to develop a child's language and cognitive skills. Through discussion, children hone their communication skills and express their feelings in bold sentences. Fourth, in dialogue activities, teachers should be able to provoke questions. The goal is to arouse the child's curiosity towards something new, develop courage and maturity to communicate, and strengthen his language skills.

Fifth, the teacher's task is to accompany children who encounter difficulties with their game. Remind and introduce children to new vocabulary. Managing classes to always be orderly and conducive. Remind your child of the rules of the game. Remind children of their role. Strengthen ideas and concepts of knowledge or experience. Tell your child about 
playtime. Ask children to clean up their play, and the most important thing is that the teacher observes, documents, records, and evaluates the child's development at the time of the game.

\section{Footing After Playing}

Footing after playing is an activity carried out by teachers and children momentarily when finished playing. The child and teacher sat back in a circle. In this activity, ask children to retell what they have done, ask feelings, display the work, and do positive reinforcement. According to Sutriyani as a class, Raudlatul Athfal Nurul Istiqomah said that on footing activities after playing, Raudlatul Athfal teacher Nurul Istiqomah did it as the BCCT approach procedure. This can be described as follows:

First, the teacher asks the child to clean the toys and keep the play in a predetermined place. Second, the teacher recalls activities that invite children to retell the experience when they acted or played the game. Third, the teacher asks the child's feelings during game activities. Fourth, the teacher again provides the fifth positive reinforcement; the teacher performs the final motivation related to the game and the learning theme.

The BCCT approach views play as the suitable medium and the only medium of child learning. In addition to fun, playing in an educational setting can be a medium for active and creative thinking (Baharun, 2015). In this BCCT, children are stimulated to actively play while learning in learning centers (Iltiqoiyah, 2020). The importance of BCCT learning can develop aspects of early childhood development, especially religious aspects of children with technological advances in the era of society 5.0. Based on learning by Basic Competence with facilities supporting technology, media can provide more stimulus to aspects of early childhood development by the stage of growth and development of children (Macia-Gual \& Domingo-Penafiel, 2020).

Teachers stimulate aspects of developing children's religious and moral values when praying before and after the learning center (Marini et al., 2018). In addition, the activity also inserted knowledge about the Creator. The application of central learning models is proven to develop aspects of children's development through the way foremost teachers who creatively seek to plan play activities and media and learning tools or materials (Takagi et al., 2020).

The development of the world of education has changed the way of thinking about what is in education (Steinbeiss, 2021). The changes made are not only the way of teaching, but the most important thing is a change in the perspective of the concept of education itself (Phusee-orn, 2021). Therefore, the development of the curriculum for the present and the future should complement the students' pedagogical dimensions, life skills, the ability to live together (collaboration), and think critically and creatively (Karabacak \& Korkmaz, 2021). Develop soft skills and transversal skills, and invisible skills useful in many work situations such as interpersonal skills, cohabitation, the ability to become a globally-minded citizen, and media and information literacy (Wibawa \& Agustina, 2019).

In addition, educators must also have leadership skills, digital literacy, communication, entrepreneurship, and problem-solving (Karacabey, 2021) because the times are increasingly advanced in all sectors (Achmad \& Miolo, 2021). If the world of education is not prepared and keeps up with the rapid development, then teaching in Indonesia will be very far behind (Raharja, 2019). Educators must be driving teachers who prioritize students, initiatives to make changes, especially for learners, take action without anyone telling, and continue to innovate and partiality to learners (Modise, 2019).

\section{CONCLUSION}

The results of the study showed that the implementation of learning with the BCCT learning model in developing religious aspects of children. In general, Raudlatul Athfal Nurul Istiqomah has adapted especially in the learning process by using learning models to develop religious aspects in children. That way, it will be easy for children in Raudlatul Athfal Nurul Istiqomah to always develop religious values with the BCCT learning model, namely first, the 
environmental footing by preparing places and conditions in the central game. Second, the footing of the experience before playing is also referred to as the opening activity before entering the core learning activities. Third, the footing when playing which is the child's activity in playing a role that is in accordance with the center. Fourth, footing after play is an activity carried out by teachers and children when they finish playing.

\section{ACKNOWLEDGMENT}

The researcher would like to thank all those who have helped complete this research, especially the Chancellor, Dean of the Faculty of Islamic Religion, Head of Study Programs, Lecturers, and the big family of Raudlatul Athfal Nurul Istiqomah. The researcher also thanks to the Editor of Obsesi: Jurnal Pendidikan Anak Usia Dini for helping to publish this article.

\section{REFERENCES}

Achmad, S., \& Miolo, S. (2021). European Journal of Educational Research. European Journal of Educational Research, 10(3), 1449-1470. https://doi.org/10.12973/eu-jer.10.3.1449

Adi, B. S., Sudaryanti, S., \& Muthmainah, M. (2020). Implementasi permainan tradisional dalam pembelajaran anak usia dini sebagai pembentuk karakter bangsa. Jurnal Pendidikan Anak, 9(1), 33-39. https:// doi.org/10.21831/jpa.v9i1.31375

Ahsanulkhaq, M. (2019). Membentuk Karakter Religius Peserta Didik Melalui Metode Pembiasaan. Jurnal Prakarsa Paedagogia, 2(1).

Alberts, W. (2019). Religious education as small "i" indoctrination: How european countries struggle with a secular approach to religion in schools. Center for Educational Policy Studies Journal, 9(4), 53-72. https://doi.org/10.26529/cepsj.688

Alfina, A., \& Anwar, R. N. (2020). Manajemen Sekolah Ramah Anak Paud Inklusi. Al-Tanzim: Jurnal Manajemen Pendidikan Islam, 4(1), 36-47. https://doi.org/10.33650/al$\underline{\operatorname{tanzim} . v 4 i 1.975}$

Almuhajir, A. (2021). Controlling the Muhammadiyah Lhokseumawe Orphanage in Forming Independent Character of Foster Children. Al-Tanzim: Jurnal Manajemen Pendidikan Islam, 5(1), 176-189. https:/ / doi.org/10.33650/al-tanzim.v5i1.1962

Astuti, A. D., Suyatno, S., \& Yoyo, Y. (2020). The Strategy of Principal In Instilling Religious Character In Muhammadiyah Elementary School. The European Educational Researcher, 3(2), 67-85. https://doi.org/10.31757/euer.323

Baharun, H. (2015). Penerapan Pembelajaran Active Learning untuk Meningkatkan Hasil Belajar Siswa di Madrasah. Pedagogik; Jurnal Pendidikan, 2(2).

Handayani, O. D. (2021). Persepsi Orangtua terhadap Pelaksanaan Belajar dari Rumah pada Pendidikan Anak Usia Dini. Jurnal Obsesi: Jurnal Pendidikan Anak Usia Dini, 5(2), 1754-1763. https://doi.org/10.31004/obsesi.v5i2.975

Heil, J., Carolus, A., Dahlkamp, J., Golatta, M., Domschke, C., Schuetz, F., Blumenstein, M., Rauch, G., \& Sohn, C. (2012). Objective assessment of aesthetic outcome after breast conserving therapy: Subjective third party panel rating and objective BCCT.core software evaluation. Breast, 21(1), 61-65. https://doi.org/10.1016/j.breast.2011.07.013

Iltiqoiyah, L. (2020). Manajemen Pembelajaran melalui Pendekatan BCCT dalam Meningkatkan Multiple intelligences Anak. Jurnal Obsesi : Jurnal Pendidikan Anak Usia Dini, 5(2), 1368-1381. https:// doi.org/10.31004/obsesi.v5i2.781

Karabacak, N., \& Korkmaz, İ. (2021). An Investigation of the Professional Values of Elementary Teachers. Educational Policy Analysis and Strategic Research, 16(2), 80-119. https://doi.org/10.29329/epasr.2020.345.5 
Karacabey, M. F. (2021). School Principal Support in Teacher Professional Development. International Journal of Educational Leadership and Management, 9(1), 54-75. https://doi.org/10.17583/ijelm.2020.5158

Lestari, N. (2019). Improving the Speaking Skill by Vlog (video blog) as Learning Media: The EFL Students Perspective. International Journal of Academic Research in Business and Social Sciences, 9(1), 915-925. https://doi.org/10.6007/IJARBSS/v9-i1/5490

Macia-Gual, A., \& Domingo-Penafiel, L. (2020). Demands in Early Childhood Education: Montessori Pedagogy, Prepared Environment, and Teacher Training. International Journal of Research in Education and Science, 7(1), 144-1162. https://doi.org/10.46328/ijres.1272

Marini, A., Safitri, D., \& Muda, I. (2018). Managing school based on character building in the context of religious school culture (Case in Indonesia). Journal of Social Studies Education Research, 9(4), 274-294. https://doi.org/10.17499/jsser.11668

Maulidia, A., \& Hanifah, U. (2020). Peran Edukasi Orang Tua terhadap PHBS AUD selama Masa Pandemi Covid-19. Musamus Journal Of Primari, 3(1), 35-44. https://doi.org/10.35724/musjpe.v3i1.3078

Modise, M. R. (2019). Supporting Culturally Diverse Early Childhood Centres in South African Townships. Bulgarian Comparative Education Society, 17, 196-202.

Nuraeni, R., \& Irawan, I. (2021). Implementation of Scientific Integration Concept Monitoring and Evaluation on The Pesantren Learning Curriculum. Altanzim: Jurnal Manajemen Pendidikan Islam, 5(2), 86-95. https:// doi.org/10.33650/al-tanzim.v5i2.2186

Nurmiyanti, L., \& Candra, B. Y. (2019). Kepemimpinan Transformasional dalam Peningkatan Mutu Pendidikan Anak Usia Dini. Al-Tanzim: Jurnal Manajemen Pendidikan Islam, 3(2), 13-24. https:// doi.org/10.33650/al-tanzim.v3i2.646

Phusee-orn, S. (2021). Comparing Practice Between Working Standard and Personal Working Standard of Teachers Who Are Certified by Attending Professional Teacher Knowledge Standard Workshop. International Education Studies, 14(9), 69. https://doi.org/10.5539/ies.v14n9p69

Preuss, J., Lester, L., \& Saunders, C. (2012). BCCT.core - Can a computer program be used for the assessment of aesthetic outcome after breast reconstructive surgery? Breast, 21(4), 597-600. https://doi.org/10.1016/j.breast.2012.05.012

Raharja, H. Y. (2019). Relevansi Pancasila Era Industry 4.0 dan Society 5.0 di Pendidikan Tinggi Vokasi. Journal of Digital Education, Communication, and Arts (Deca), 2(1), 11-20. https://doi.org/10.30871/deca.v2i1.1311

Rasyad, M., Maesaroh, S., \& Junanah. (2020). Metode edukasi dan pelatihan konten anak nusantara di kecamatan ngaglik kabupaten sleman. Jurnal Mahasiswa FIAI-UII, atThullab, 1(2), 205-221.

Rozi, F., Tohet, M., Aini, Q., \& Imamah, N. N. (2022). Anger Management in Improving Teacher Performance in School. Al-Tanzim: Jurnal Manajemen Pendidikan Islam, 6(1), 243-253.

Steinbeiss, G. (2021). B Eginning Student Teachers ' Professional Identity 1. Acta Didactica Napocensia, 14(1), 151-164. https:// doi.org/10.24193/adn.14.1.12

Subaidi. (2020). Strengthening character education in Indonesia: Implementing values from moderate Islam and the Pancasila. Journal of Social Studies Education Research, 11(2), 120-132. 
Susilowati, S., \& Farida, I. (2019). Strategi Pengembangan Sumber Daya Manusia Di Pt. Gaya Sukses Mandiri Kaseindo ( Safeway) Surabaya. Develop, 3(2), 10-25. https:// doi.org/10.25139/dev.v3i2.1772

Syafii, M. L., Santoso, S., \& Harotno, S. (2021). Story-telling Technique Utilizing Puppets to Enhance the Learners' Speaking Competence. International Journal on Social and Education Sciences, 3(2), 304-341. https://doi.org/10.46328/ijonses.70

Takagi, Y., Batten, P., \& Rattenborg, K. (2020). a Collaborative Exchange To Improve Early Childhood Education Outcomes. Problems of Education in the 21st Century, 78(6A), 1126-1136. https:// doi.org/10.33225/pec/20.78.1126

Wibawa, R. P., \& Agustina, D. R. (2019). Peran Pendidikan Berbasis Higher Order Thinking Skills (HOTS) pada Tingkat Sekolah Menengah Pertama di Era Society 5.0 sebagai Penentu Kemajuan Bangsa Indonesia. Equilibrium, 7(2), 137-141. https://doi.org/10.25273/equilibrium.v7i2.4779

Yu, T., Eom, K. Y., Jang, N. Y., Kim, K. S., Koo, T. R., Kwon, J., Kim, B. H., Kang, E., Kim, S. W., Kim, J. S., \& Kim, I. A. (2016). Objective measurement of cosmetic outcomes of breast conserving therapy using BCCT.core. Cancer Research and Treatment, 48(2), 491-498. https://doi.org/10.4143/crt.2015.088 